\title{
Arsenic toxicity and carcinogenesis: a public health risk assessment and management approach
}

\author{
P. B. Tchounwou \\ NIH-RCMI Center for Environmental Health, College of Science, \\ Engineering and Technology, Jackson State University, Jackson, \\ Mississippi, USA
}

\begin{abstract}
Acute and chronic exposure to arsenic has been reported in several countries of the world, with major outbreaks of arsenosis occurring in Argentina, Bangladesh, India, Mexico, Thailand, and Taiwan, where a large proportion of drinking water (groundwater) is contaminated with high concentrations of arsenic. Research has also pointed to significantly higher standardized mortality rates for cancers of the bladder, kidney, skin, liver, and colon in many areas of arsenic pollution. There is therefore a great need for developing a comprehensive risk assessment model that should be used in the effective management of health risks associated with arsenic exposure. With a special emphasis on arsenic toxicity and carcinogenesis, this paper aims at developing and presenting a conceptual risk assessment and management model. Using the National Academy of Science's risk assessment and management framework as a guide, all critical information has been analyzed and presented with respect to the health hazard, the sources and pathways of human exposure, the concept of the dose-response relationship in arsenic poisoning, the characterization of both systemic and carcinogenic effects, and the potential strategies to control and/or prevent arsenic poisoning.

Keywords: arsenic exposure, toxicity, health effects, risk assessment and management.
\end{abstract}

\section{Introduction}

Arsenic is released into the environment from natural sources as a result of natural phenomena such as the erosion of mineral deposits and volcanoes, but 
releases from human activities such as metal smelting, coal combustion, chemical production and use, and waste disposal can lead to substantial contamination of the environment [1,2]. The National Academy of Science estimates that about 75,000 to 100,000 tons of arsenic is produced annually on a global scale [3]. More than $80 \%$ of arsenic compounds are used to manufacture products with agricultural applications such as insecticides, herbicides, fungicides, algicides, sheep dips, wood preservatives, dyestuffs, and medicines for the eradication of tapeworms in sheep and cattle. Arsenic compounds have been used for at least a century in the treatment of syphilis, yaws, amoebic dysentery, and trypanosomiasis [3]. Arsenical drugs are still used in treating certain tropical diseases such as African sleeping sickness and amoebic dysentery, and in veterinary medicine to treat parasitic diseases, including filariasis in dogs and black head in turkeys and chickens [3]. Recently, arsenic has been used as an anticancer agent in the treatment of acute promeylocytic leukemia, and its therapeutic action has been attributed to the induction of programmed cell death (apoptosis) in leukemia cells [4-6].

In recent years, arsenic contamination of natural resources (ground water) has emerged as one of the major environmental health issues in several countries of the world. Outbreaks of arsenosis and other health effects associated with ground water contamination in Argentina, Bangladesh, Chili, China, Mexico, India, Thailand, and Taiwan are examples of such concerns [7, 8]. Arsenic exposure has lead to a significant number of health concerns including hyperkeratosis, jaundice, vascular diseases, and cancer of various organs/tissues including the skin, liver, lung and bladder [8].

The mechanism by which arsenic exerts its toxic effect is through impairment of cellular respiration by the inhibition of various mitochondrial enzymes, and the uncoupling of oxidative phosphorylation. Most toxicity of arsenic results from its ability to interact with sulphydryl groups of proteins and enzymes, and to substitute phosphorus in a variety of biochemical reactions. Although the evidence of carcinogenicity of arsenic in humans seems strong, the mechanism by which it produces tumors in humans is not completely understood. In contrast to most other human carcinogens, it has been difficult to confirm the carcinogenicity of arsenic in experimental animals. Research evaluating the chronic effects in laboratory animals exposed to inorganic and organic arsenic compounds by the oral route or skin contact, has not shown any potential for initiation or promotion of carcinogenicity $[8,9]$.

Based on its high degree of toxicity to humans, and the non-threshold doseresponse assumption, a zero level exposure is being recommended for arsenic even though it is practically non attainable [7]. As with other human carcinogens, the development of a comprehensive risk assessment (RA) and risk management (RM) protocol for arsenic requires a thorough understanding of the four components (hazard identification, dose-response assessment, exposure assessment, and risk characterization) of the RA paradigm, and an evaluation of RM options related to arsenic contamination [3]. 


\section{Hazard identification}

There are many case reports of death in humans due to ingestion of high doses of arsenic. The clinical manifestations of arsenic poisoning depend on the type of arsenical involved and on the duration of exposure. Symptoms of acute intoxication usually occur within 30 minutes of ingestion but may be delayed if arsenic is taken with food. In nearly all cases, the most immediate effects are severe nausea and vomiting, colicky abdominal pain, profuse diarrhea with rice stools, gastrointestinal hemorrhage and death may ensue from fluid loss and circulatory collapse. Drowsiness and confusion are often seen along the development of psychosis associated with paranoid delusions, hallucinations and delirium. Finally, seizures, coma and death, usually due to shock, may ensue [10]. Cardiac manifestations include acute cardiomyopathy, subendocardial hemorrhages, and electro-cardiographic changes. The pathological lesions described in patients with rapidly fatal arsenic intoxication are fatty degeneration of the liver, hyperemia and hemorrhages of the gastrointestinal tract, renal tubular necrosis, and demyelination of peripheral nerves [10]. Chronic exposure to arsenic affects the gastrointestinal tract, circulatory system, skin, liver kidneys, nervous system and heart. There is clear evidence from epidemiological studies that exposure to inorganic arsenic increases the risk of cancer [11]. When exposure occurs by the oral route, the main carcinogenic effect is increased risk of skin cancer. In addition to skin cancer, increased risk of other internal tumors (mainly of liver, kidney, lung, and bladder) have been reported with arsenic exposure $[12,13]$. Table 1 presents a synopsis of clinical and pathological manifestations in acute and chronic arsenic poisoning [10].

Experimentally, arsenicals are fetotoxic and teratogenic in laboratory animals $[14,15]$. The common developmental effects seen include malformations of the brain, urogenital organs, skeleton, ear, as well as small or missing eyes. Generally, these are only seen at doses that also result in maternal toxicity. In vitro experiments with many arsenicals have shown that they are powerful clastogens in many cell types. Tests for genotoxicity have indicated that arsenic compounds inhibit DNA repair, and induce chromosomal aberrations, and sister chromatid exchanges [8]. There are also several epidemiological studies reporting an association between exposure to inorganic arsenic and increased risk of adverse developmental effects such as congenital malformations, low birth weight, and spontaneous abortion [15].

\section{Dose-response assessment}

It has been demonstrated that the risk of arsenic intoxication increases as a function of exposure level and duration. The National Research Council of Canada reported that 9,16 and $44 \%$ incidence of symptoms of arsenic poisoning are observed at drinking water arsenic concentrations of 50, 50-100, and $>100$ $\mathrm{ug} / \mathrm{L}$, respectively [16]. The frequencies of skin cancer associated with arseniccontaminated water have been reported by the U.S. EPA as $0.26 \%$ and $2.14 \%$ at 290 and $600 \mathrm{ug} / \mathrm{L}$, respectively. Also, cancer risks of $10^{-5}, 10^{-6}$, and $10^{-7}$ have 
Table 1: Clinical and pathological manifestations of acute and chronic arsenic poisoning.

\begin{tabular}{|c|c|c|}
\hline Organ/Tissue Level & Acute Effects & Chronic Effects \\
\hline - Dermatologic & $\begin{array}{ll}\text { - } & \text { Capillary flush } \\
\text { - } & \text { Contact dermatitis } \\
\text { - } & \text { Folliculitis } \\
\text { - } & \text { Hair loss }\end{array}$ & $\begin{array}{ll}\text { - } & \text { Melanosis } \\
\text { - } & \text { Bowen's disease } \\
\text { - } & \text { Facial edema } \\
\text { - } & \text { Palmoplantar } \\
& \text { hyperkeratosis } \\
\text { - } & \text { Cutaneous } \\
& \text { malignancies } \\
\text { - } & \text { Hyperpigmentation } \\
\text { - } & \text { Desquamation }\end{array}$ \\
\hline - Neurologic & $\begin{array}{ll}\text { - } & \text { Hyperpyrexia } \\
\text { - } & \text { Convulsions } \\
\text { - } & \text { Tremor / Coma } \\
\text { - } & \text { Disorientation }\end{array}$ & $\begin{array}{ll}\text { - } & \text { Encephalopathy } \\
\text { - } & \text { Headache } \\
\text { - } & \text { Peripheral neuropathy } \\
\text { - } & \text { Axonal degeneration }\end{array}$ \\
\hline $\begin{array}{ll} & \text { Gastro- } \\
\text { intestinal/ } \\
\text { Hepatic }\end{array}$ & $\begin{array}{ll}\text { - } & \text { Abdominal pain } \\
\text { - } & \text { Dysphagia } \\
\text { - } & \text { Vomiting } \\
\text { - } & \text { Blood/rice water } \\
& \text { diarrhea } \\
\text { - } & \text { Garlicky odor to } \\
& \text { breath } \\
\text { - } & \text { Mucosal erosions } \\
\text { - } & \text { Fatty liver } \\
\text { - } & \text { Cholangitis } \\
\text { - } & \text { Cholecystitis } \\
\end{array}$ & $\begin{array}{ll}\text { - } & \text { Nausea } \\
\text { - } & \text { Vomiting } \\
\text { - } & \text { Diarrhea } \\
\text { - } & \text { Anorexia } \\
\text { - } & \text { Weight loss } \\
\text { - } & \text { Hepatomegaly } \\
\text { - } & \text { Jaundice } \\
\text { - } & \text { Pancreatitis } \\
\text { - } & \text { Cirrhosis } \\
\text { - } & \text { Liver cancer }\end{array}$ \\
\hline - $\quad$ Renal & $\begin{array}{ll}\text { - } & \text { Tubular damage } \\
\text { - } & \text { Glomerular } \\
& \text { damage } \\
\text { - } & \text { Oligura } \\
\text { - } & \text { Uremia }\end{array}$ & $\begin{array}{ll}\text { - } & \text { Nephritis } \\
\text { - } & \text { Proteinuria }\end{array}$ \\
\hline - Hematologic & $\begin{array}{ll} & \text { Anemia } \\
\text { - } & \text { Thrombocytopenia }\end{array}$ & $\begin{array}{ll}\text { - } & \text { Bone marrow } \\
& \text { hypoplasia } \\
\text { - } & \text { Anemia } \\
\text { - } & \text { Thrombocytopenia } \\
\text { - } & \text { Basophilic stippling } \\
\text { - } & \text { Karyorrhexis }\end{array}$ \\
\hline
\end{tabular}




\section{Table 1: $\quad$ Continued.}

\begin{tabular}{|c|c|c|}
\hline $\begin{array}{l}\text { - Cardio- } \\
\text { vascular }\end{array}$ & $\begin{array}{ll}\text { - } & \text { Ventricular } \\
& \text { fibrillation } \\
\text { - } & \text { Tachycardia }\end{array}$ & $\begin{array}{ll}\text { - } & \text { Arrhythmias } \\
\text { - } & \text { Pericarditis } \\
\text { - } & \text { Acrocyanosis } \\
\text { - } & \text { Raynaud's, and } \\
\text { gangrene }\end{array}$ \\
\hline - Respiratory & $\begin{array}{ll}\text { - } & \text { Pulmonary edema } \\
\text { - } & \text { Bronchial } \\
\text { pneumonia } \\
\text { - } \quad \text { Tracheo-bronchitis }\end{array}$ & $\begin{array}{ll}\text { - } & \text { Cough } \\
\text { - } & \text { Pulmonary fibrosis } \\
\text { - } & \text { Lung cancer }\end{array}$ \\
\hline
\end{tabular}

been estimated for drinking water containing $0.022,0.0022$, and $0.00022 \mathrm{ug}$ As/L, or for eating aquatic organisms living in contaminated water containing $0.175,0.0175$, and $0.00175 \mathrm{ug} \mathrm{As} / \mathrm{L}$ [17]. In a study of cancer prevalence in patients treated with Fowler's solution (1\% potassium arsenite concoction), a dose-response relationship was found between the ingested dose of Fowler's solution and the incidence of skin cancer. In patients who ingested 200 to 800 $\mathrm{mL}$ of Fowler's solution (1.6 to $6 \mathrm{~g}$ of arsenic), the prevalence of skin cancer was 5 to $10 \%$, while patients treated with the Fowler's solution at an equivalent arsenic dose of $7.6 \mathrm{~g}$ had a prevalence of $20 \%$ [18]. A strong dose-response relationship between arsenic concentration in drinking water and skin cancer mortality has been documented in the endemic area of blackfoot disease in Taiwan. Similar correlations have been reported between arsenic levels in drinking water and age-adjusted mortality rates for cancers of the lung, liver, bladder, kidney, and colon [19]. Experimental studies have also reported a strong dose-response relationship between the level of arsenic exposure and the magnitude of adverse effects, both in vivo [20] and in vitro [21].

\section{Exposure assessment}

A very large number of people are exposed to arsenic chronically throughout the world. Exposure to arsenic occurs via the oral route (ingestion), inhalation, dermal contact, and the parenteral route to some extent. For most people, the diet is the largest source of arsenic exposure, with an average intake of about $50 \mathrm{ug}$ per day. Intake from air, water and soil are usually much smaller, but exposure from these media may become significant in areas of arsenic contamination. People who produce or use arsenic compounds in occupations such as nonferrous metal smelting, pesticide manufacturing and application, wood preservation, semiconductor manufacturing, or glass production can be exposed by substantially higher levels of arsenic [8, 10, 18, 19]. As stated earlier, different species of arsenic have different degrees of toxicity, with arsine and the trivalent arsenic causing the most injury [22]. In addition to the exposure route and the arsenic species involved, the toxicity also depends on the exposure dose, frequency, duration, the biological species, age, and gender, as well as on individual susceptibilities, genetic and nutritional factors $[8,16,19]$. 


\section{Risk characterization}

A review of biological properties and toxic effects of arsenic indicates that this chemical is a systemic toxicant capable of causing a significant number of health effects including: cardiovascular disease, peripheral vascular disease, developmental effects, neurologic and neurobehavioral effects, diabetes, hearing loss, portal fibrosis of the liver, lung fibrosis, hematologic effects (anemia, leukopenia, and eosinophilia), and carcinogenic effects [2, 7, 8, 16, 19, 22]. Studies in Taiwan have reported that in areas where blackfoot disease is endemic, the standardized and cumulative mortality rates were significantly higher for cancer of the bladder, kidney, skin, liver, lung and colon. These studies have also pointed out that the lifetime risks for developing cancer due to an arsenic intake of $10 \mathrm{ug} / \mathrm{kg} /$ day were $0.012,0.0043,0.012$, and 0.0042 in male residents for cancers of the lung, liver, bladder, and kidney, respectively [19]. The corresponding figures for female residents were $0.013,0.0036,0.017$, and 0.0043 [19]. The International Agency for Research on Cancer, and the U.S. EPA classify arsenic in Group 1/A-known human carcinogens [23, 24]. The oral reference dose $(\mathrm{RfD})$ is $3 \times 10^{-4} \mathrm{mg} / \mathrm{kg} /$ day, and the cancer potency factor is 1.75 $(\mathrm{mg} / \mathrm{kg} / \mathrm{day})^{-1}[24]$.

\section{Risk management}

Because of its high potential to cause adverse effects in exposed persons, a number of regulations and guidelines have been established for various inorganic and organic forms of arsenic by international, federal, and state agencies. In 1976, the permissible limit for arsenic in drinking water (maximum contaminant level) was fixed at $50 \mathrm{ug} / \mathrm{L}$ [25]. In 1999, the National Research Council of the National Academy of Science recommended a standard of $10 \mathrm{ug} / \mathrm{L}$ [26]; a standard that has just been adopted by the Bush Administration. The World Health Organization=s tolerable daily intake for inorganic arsenic is $2 \mathrm{ug} / \mathrm{kg} \mathrm{BW} \mathrm{[27].} \mathrm{The} \mathrm{action} \mathrm{level}$ for arsenic in the air is $5 \mathrm{ug} / \mathrm{m}^{3}$. The permissible exposure limit-total weighted average (PEL - TWA) is $10 \mathrm{ug} / \mathrm{m}^{3}$ for inorganic arsenicals, and $500 \mathrm{ug} / \mathrm{m}^{3}$ for organic arsenicals [28]. British Anti-Lewisite (BAL or 2,3-Dimercaptopropanol) has been used to treat acute dermatitis, and the pulmonary symptoms associated with arsenic exposure. However, because of the side effects associated with BAL, other agents such as sodium 2,3-dimercapto-1-propane sulfonate (DMPS or Dimaval), and dimercaptosuccinic acid (DMSA) are being tested for the chelation therapy of arsenic poisoning [8, 16]. The atomic absorption spectrophotometry (AAS) appears to be the most common analytical method used for arsenic analysis; more sophisticated techniques, however, such as HPLC-FGAAS, and ICP-MS, are highly valuable when arsenic speciation is required [7]. Removal of arsenic from drinking water by appropriate technologies is one of the most important control and management strategies. Several treatment methods including chemical precipitation (coagulation processes), ion exchange, reverse osmosis/electrodialysis, use of activated alumina or carbon, and oxidation, have therefore been recommended for arsenic removal in water [29]. 
In conclusion, arsenic poisoning appears to be one of the major public health problems of pandemic nature. The development of a comprehensive risk assessment and management model for arsenic requires a thorough understanding of its physical and chemical properties, production and use, fate and transport, toxicokinetics, systemic and carcinogenic health effects, regulatory and health guidelines, analytical guidelines and treatment technologies. A comprehensive analysis of published data indicate that arsenic exposure induces cardiovascular diseases, developmental abnormalities, neurologic and neurobehavioral disorders, diabetes, hearing loss, heamatologic disorders, and various types of cancer. There exist various sources of exposure. Although exposure may occur via the dermal, and parenteral routes, the main pathways of exposure include ingestion, and inhalation. The severity of adverse health effects is related to the chemical form of arsenic, and is also time- and dose-dependent. From a management point of view, several control and treatment technologies, as well as regulatory guidelines have been developed to address the issue of arsenic toxicity and carcinogenesis.

\section{Acknowledgements}

This research was financially supported in part by a grant from the National Institutes of Health (No. 1G12RR13459), and in part by a grant from the Department of the Army (No. W912HZ-04-2-0002). The author thanks Dr. Richard Price of the Army Engineering Research \& Development Center for his support of this project.

\section{References}

[1] Centeno, J.A., Tchounwou P.B., Patlolla A.K., Mullick F.G., Murakat L, Meza E., Gibb H., Lonfellow D., \& Yedjou C. Environmental pathology and health effects of arsenic poisoning. In Naidu R., Smith J., \& Bhattachara P., Eds. Managing Arsenic in the Environment: From Soil to Human Health. CSIRO Publishing Corp. Adelaide, Australia, 2006.

[2] Tchounwou P.B., Patlolla A.K., \& Centeno J.A. Carcinogenic and systemic health effects associated with arsenic exposure-A critical review. Toxicologic Pathology, 31, pp.1-14, 2003.

[3] NAS. Arsenic. National Academy of Science. Washington D C, 1977.

[4] Rousselot P., Laboume S., Marolleau J.P., Larghero T., Noguera M.L., Brouet J.C., \& Fermand J.P. Arsenic trioxide and melarsoprol induce apoptosis in plasma cell lines and in plasma cells from myeloma patients. Cancer Research, 59, pp. 1041-1048, 1999.

[5] Yedjou G.C., \& Tchounwou P.B. In-vivo cytotoxic and genotoxic effects of arsenic trioxide on human leukemia cells using the MTT and alkaline single cell gel electrophoresis assays. Molecular and Cellular Biochemistry (In Press), 2007.

[6] Yedjou G.C., Moore P., \& Tchounwou P.B. Dose and time dependent response of human leukemia (HL-60) cells to arsenic trioxide. International 
Journal of Environmental Research and Public Health, 3(2), pp. 136-140, 2006.

[7] Tchounwou P.B., Wilson B., \& Ishaque A. Important considerations in the development of public health advisories for arsenic and arsenic-containing compounds in drinking water. Reviews on Environmental Health, 14, pp. 119, 1999.

[8] ASTDR. Toxicological Profile for Arsenic TP-92/09. Agency for Toxic Substances and Disease Registry. Center for Disease Control, Atlanta, GA, 1993.

[9] Goyer R.A. Toxic effects of metals. In: Klaassen CD ed. Cassarett \& Doull=s Toxicology-The Basic Science of Poisons. McGraw Hill. New York, NY. pp. 691-736, 1996.

[10] Gorby MS. Arsenic in human medicine. In: Nriagu JO, ed. Arsenic in the Environment; Part II: Human Health and Ecosystem Effects. New York, NY: John Wiley \& Sons, Inc., pp. 1-16, 1994.

[11] Wu M.M., Kuo T.L., \& Hwang Y.H. Dose-response relation between arsenic concentration in well water and mortality from cancers and vascular diseases. American Journal of Epidemiology, 130, pp. 1123-1132, 1989.

[12] Tseng W.P., Chu H.M., How S.W., Fong J.M., Lin C.S., \& Yeh S. Prevalence of skin Cancer in an endemic area of chronic arsenicism in Taiwan. Journal of the National Cancer Institute, 40, pp. 453-463, 1968.

[13] Chen C.J., Chen C.W., Wu M.M., \& Kuo T-L. Cancer potential in liver lung, bladder and kidney due to ingested inorganic arsenic in drinking water. British Journal of Cancer, 66, pp. 888-892, 1992.

[14] Tchounwou P.B., Wilson B., \& Ishaque A.B. Embryotoxicity of arsenic trioxide and atrazine to Japanese medaka fish. In Greenberg B.M., Hull R.N., Roberts M.H., \& Gensemer R.W. Eds. Environmental Toxicology and Risk Assessment: Science Policy and Standardization-Implications for Environmental Decisions. American Society for Testing and Materials. West Conshohocken, PA. STP 1403, pp. 83-95, 2001.

[15] Aschengran A., Zierler S., Cohen A. Quality of community drinking water and the occurrence of spontaneous abortion. Archives of Environmental Health, 44, pp. 283-290, 1989.

[16] NRCC. Effects of arsenic in the environment. National Research Council of Canada. Natl Res Counc Can Publ, pp. 1-349, 1978.

[17] U.S. EPA. Ambient Water Quality Criteria for Arsenic. EPA 400/5-80-021. Environmental Protection Agency. Washington DC, 1980.

[18] Fierz U. Catamnestic investigations of the side effects of therapy of skin diseases with inorganic arsenic. Dermatologia, 131, 41-58, 1965.

[19] Chen C.J., \& Lin L.J. Human carcinogenicity and atherogenicity induced by chronic exposure to inorganic arsenic. In: Nriagu JO, ed. Arsenic in the Environment; Part II: Human Health and Ecosystem Effects. New York, NY: John Wiley \& Sons, Inc., pp. 109-131, 1994.

[20] Patlolla A.K., \& Tchounwou P.B. Cytogenetic evaluation of arsenic trioxide toxicity in Sprague-Dawley rats. Mutation Research-Cenetic Toxicology and Environmental Mutagenesis, 587(1-2), pp. 126-133, 2005. 
[21] Tchounwou P.B., Yedjou G.C., \& Dorsey W. Cytotoxicity and transcriptional activation of stress genes in human liver carcinoma cells exposed to arsenic trioxide. Molecular and Cellular Biochemistry, 255, pp. 47-55, 2004.

[22] Tchounwou P.B., Wilson B.A., Abdelghani A.A., Ishaque A.B., \& Patlolla A.K. Differential cytotoxicity and gene expression in human liver carcinoma cells exposed to arsenic trioxide and monosodium acid methylarsonate. International Journal of Molecular Sciences, 3(10), pp. 1117-1132, 2002.

[23] IARC. Monographs on the Evaluation of Carcinogenic Risks of Chemicals to Humans. Supplement F. Overall Evaluation of Carcinogenicity. International Agency for Research on Cancer. World Health Organization. Lyon, France, pp. 29-57, 1987.

[24] IRIS. Integrated Risk Information System. U.S. EPA. Washington, DC, 1992.

[25] U.S. EPA. National primary drinking water regulations. Federal Register, 50, pp. 46931-47022, 1985.

[26] National Research Council. Arsenic in drinking water. 2001 update. On line at: http://www.nap.edu/ books/0309076293/ html/

[27] WHO. Guidelines for Drinking Water Quality. World Health Organization, Geneva, Switzerland, 1984.

[28] OSHA. Occupational Safety and Health Administration. Federal Regulation, 54, pp. 2332-2335, 1989.

[29] Jekel MR. Removal of arsenic in drinking water treatment. In Nriagu JO ed. Arsenic in the Environment, Part I: Cycling and Characterization. New York, NY: John Wiley \& Sons, Inc. pp. 119-132, 1994. 